Article

\title{
Student Engagement and Blended Learning: Making the Assessment Connection
}

\author{
Norman Vaughan \\ Department of Education, Mount Royal University, 4825 Mount Royal Gate SW, \\ Calgary AB T3E 6K6, Canada; E-Mail: nvaughan@mtroyal.ca; Tel.:403-440-5587 \\ External Editor: Anthony G. Picciano
}

Received: 19 October 2014; in revised form: 18 November 2014 / Accepted: 19 November 2014 / Published: 27 November 2014

\begin{abstract}
There is an increased focus on student engagement and blended approaches to learning in higher education. This article demonstrates how collaborative learning applications and a blended approach to learning can be used to design and support assessment activities that increase levels of student engagement with course concepts, their peers, faculty and external experts, leading to increased student success and satisfaction.
\end{abstract}

Keywords: student engagement; collaborative learning applications; blended learning; assessment

\section{Introduction}

Over the past decade, there has been an increased focus on the topic of student engagement in higher education in light of rising tuition costs and concerns about student success and retention rates [1]. In order to address these issues, Littky and Grabelle [2] advocate for a curriculum redesign that stresses relevance, rigor, and relationships (3R's of engagement). It has been suggested that such a redesign would enable students to meaningfully engage in sustained learning experiences that may lead to a state of optimal flow, which Csíkszentmihályi [3] defines as "the mental state of operation in which the person is fully immersed in what he or she is doing by a feeling of energized focus, full involvement, and success in the process of the activity" [3] (p. 9). Pink [4] suggests that students can achieve this state of "flow" by educators providing them with opportunities to become "driven" 
learners who have a sense of purpose, are autonomous, and are focused on mastery learning. And, Fullan [5] stresses that optimal flow is achieved by creating learning environments that focus on purpose, passion, and play (3P's of engagement).

In 1998, the National Survey of Student Engagement (NSSE) was developed as a "lens to probe the quality of the student learning experience at American colleges and universities” [6] (p. 3). The NSSE defines student engagement as the amount of time and effort that students put into their classroom studies that lead to experiences and outcomes that constitute student success, and the ways the institution allocates resources and organizes learning opportunities and services to induce students to participate in and benefit from such activities. Five clusters of effective educational practice have been identified based on a meta-analysis of the literature related to student engagement in higher education. These benchmarks are [6]:

(1) Active and collaborative learning

(2) Student interactions with faculty members

(3) Level of academic challenge

(4) Enriching educational experiences

(5) Supportive campus environment

Recently, the educational research literature [7] has indicated that blended approaches to learning might provide an optimal environment for enhancing student engagement and success. The idea of blending different learning experiences has been in existence since humans started thinking about teaching [8]. The on-going infusion of web-based technologies into the learning and teaching process has highlighted the potential of blended learning $[9,10]$. Collaborative web-based applications have created new opportunities for students to interact with their peers, teachers, and content.

Blended learning is often defined as the combination of face-to-face and online learning $[11,12]$. Ron Bleed, the former Vice Chancellor of Information Technologies at Maricopa College, argues that this is not a sufficient definition for blended learning as it simply implies "bolting” technology onto a traditional course, using digital technologies as an add-on to teach a difficult concept, or adding supplemental information. He suggests that blended learning should be viewed as an opportunity to redesign how courses are developed, scheduled, and delivered through a combination of physical and virtual instruction: "bricks and clicks" [13]. Joining the best features of in-class teaching with the best features of online learning that promote active, self-directed learning opportunities with added flexibility should be the goal of this redesigned approach [14-16]. Garrison and Vaughan [17] echo this sentiment when they state that "blended learning is the organic integration of thoughtfully selected and complementary face-to-face and online approaches and technologies” [17] (p. 148). A survey of e-learning activity conducted by Arabasz, Boggs and Baker [18], over ten years ago, found that 80 percent of all higher education institutions and 93 percent of doctoral institutions offer hybrid or blended learning courses.

Most of the recent definitions for blended courses indicate that this approach to learning offers potential for improving how we deal with content, social interaction, reflection, higher order thinking, problem solving, collaborative learning, and more authentic assessment in higher education, which could potentially lead to a greater sense of student engagement [16,19,20]. Moskal, Dziuban and Hartman [21] further suggest that "blended learning has become an evolving, responsive, and dynamic 
process that in many respects is organic, defying all attempts at universal definition” [21] (p. 15). In this chapter, the author defines blended learning as the intentional integration of synchronous and asynchronous learning opportunities.

The literature also suggests that the use of collaborative learning applications such as social networking sites, blogs, and wikis has been increasing in higher education courses but that there has been a lack of corresponding research about how these tools are impacting student learning and engagement [22]. Can these tools be used to design and support assessment activities that increase the level of student engagement with course concepts, their peers, faculty and external experts, potentially leading to increased student success and satisfaction in a blended learning environment?

A study was conducted to investigate the impact of collaborative learning applications (e.g., blogs, wikis, clickers, social media sharing, and networking applications) on student learning and engagement in first year undergraduate courses designed for blended learning. The study addressed the following questions:

(1) How are instructors designing assessment activities to incorporate student use of collaborative learning applications in blended courses?

(2) How do students perceive the value of these digital tools?

(3) Is there a correlation between the use of these tools, the level of perceived student engagement, and academic achievement in blended courses?

The use of collaborative learning applications was examined in seven, first-year blended learning courses from different disciplines at Mount Royal University in Canada (Biology, Business, Child and Youth Studies, Communication Studies, Economics and General Education-Controversies in Science and Creativity in the Workplace).

\section{Theoretical Framework}

The collaborative constructivism framework developed by Garrison and Archer [23] and the theoretical foundations of the National Survey of Student Engagement (NSSE) underpin this research study. Garrison and Archer [23] trace the origins of collaborative constructivism back to Dewey [24] who argued that "meaningful and educationally worthwhile knowledge is a process of continuous and collaborative reconstruction of experience” [23] (p. 11). They indicate that meaningful and worthwhile learning outcomes are facilitated in a collaborative environment where individual students are recognized and supported, a variety of perspectives are presented and examined, and misconceptions are diagnosed.

The NSSE examines the relationship between student engagement and student success in higher education institutions throughout the world [25]. The NSSE conceptions of student engagement in higher education are grounded in several decades of prior research, and particularly in four key antecdents: Pace's [26] “quality of effort” concept, Astin's [27] theory of student involvement, Chickering and Gamson's [28] principles of good practice in undergraduate education, and Pascarella and Terenzini’s [29] causal model of learning and cognitive development. 


\section{Methods of Investigation}

An action research [30] and case-based method [31] were utilized for this study. This approach consisted of a mixture of quantitative (e.g., online surveys) and qualitative (e.g., interviews, focus groups) research methods.

\subsection{Data Collection}

Data was collected from two iterations of the seven, first-year blended learning courses over a two-year period. A total of 273 students and 8 instructors participated in this study. This project received Mount Royal University Ethics Approval and both students and instructors signed informed consent forms. The consent forms offered the participants confidentiality and the ability to withdraw from the study at any time.

The data collection process began with pre-course interviews with all the instructors involved in the seven blended courses. The purpose of these interviews was to identify how instructors were planning to use collaborative learning applications, in alignment with assessment activities, to help students achieve the intended course learning outcomes.

A 75 item online survey was designed to collect demographic data, information concerning student use of collaborative learning technologies, and perceptions about student engagement. Items used in the survey were derived from the Classroom Assessment of Student Engagement (CLASSE-the classroom version of the National Survey of Student Engagement) [32] and the EDUCAUSE Centre for Applied Research Study of Undergraduate Students and Information Technology [33]. The Flashlight Online Survey Tool [34] was used to administer the survey to both students and faculty in all seven blended courses. The survey was deployed during the tenth week of the semester, in two iterations of each course. The tenth week was selected so that students would have had sufficient exposure to the collaborative learning applications in their blended courses to provide the author with meaningful feedback and so that there would be time for a student focus group meeting before the end of the semester.

Student focus groups were facilitated and digitally recorded using a standardized protocol by an undergraduate research assistant (URA) during the eleventh week of the semester for the first iteration of each course. The URA was an education student who received training from the author of this study and she used a series of open-ended questions, generated from the survey results, to guide the focus groups. These focus groups were limited to the first iteration of each course due to budget constraints. Approximately ten students attended each of the seven focus groups (e.g., one for each blended course), which provided an opportunity to discuss and verify the findings from the online surveys.

Students' level of use of Blackboard, the institutional learning management system (LMS), was also assessed using page hits per student per course. Academic achievement was defined as students' final grade in the blended course under study.

Reports were prepared for each of the seven blended courses and post-course interviews were digitally recorded with each of the instructors at the end of the semester depending on when the second iteration of the course took place. In addition, a focus group lunch was held with all the instructors in order to review and discuss the preliminary data collected. 


\subsection{Data Analysis}

\subsubsection{Quantitative Data}

Descriptive statistics (frequencies, means, and standard deviations) were calculated for individual survey items. Scale scores were computed for the following engagement-related parameters using methods described elsewhere (http://nsse.iub.edu/\#construction_of_nsse_benchmarks): active and collaborative learning; student-faculty interaction; level of academic challenge; and engagement in effective educational practices. A scale score reflecting intensity of students' course-related digital technology use was calculated based on responses to selected survey items. Cronbach alpha coefficients were utilized to assess the internal reliability of calculated scales. Descriptive statistics (range, mean, and standard deviation) were used to depict level of use of the LMS. Pearson correlation coefficients and analysis of variance were used to assess the association between engagement measures, digital technology use, and academic achievement.

\subsubsection{Qualitative Data}

Interviews and focus group sessions were digitally recorded and transcribed by the URA. A constant comparative approach was used to identify patterns, themes, and categories of analysis that "emerge out of the data rather than being imposed on them prior to data collection and analysis" [35] (p. 390). These transcripts were reviewed and compared with the responses from the open-ended online survey questions in order to triangulate themes and patterns.

\section{Findings}

This section begins with a demographic and digital technology ownership profile of the study participants followed by a summary of the results for each of the three research questions:

(1) How are instructors designing assessment activities to incorporate student use of collaborative learning applications in blended courses?

(2) How do students perceive the value of these digital tools?

(3) Is there a correlation between the use of these tools, the level of perceived student engagement in these courses, and academic achievement in blended courses?

\subsection{Demographic Profile and Technology Ownership of the Study Participants}

Student Demographics

In order to establish a context for the study findings, the student version of the online survey asked a series of demographic questions. The survey response rate was 53\% for students $(n=273)$ and $100 \%$ for faculty $(n=8)$. The demographic profile of the students is summarized in Table 1.

The vast majority of respondents were first year students who were employed and commuted to campus. Respondents were primarily under the age of twenty-five. Over two-thirds were female. The demographic profile of student participants reflected that of the university as a whole with respect to gender, age, employment status, residence, and level of course enrollment [36]. 
Table 1. Survey respondent demographics.

\begin{tabular}{ll}
\hline Item & Percentage/Number \\
\hline Female & $69 \%$ \\
24 years of age or less & $82 \%$ \\
Employed (part-time 62\%; full-time 13\%) & $75 \%$ \\
Average hours of work per week & 16 \\
Off-campus accommodation within driving distance & $84 \%$ \\
First year of studies & $75 \%$ \\
Average number of courses enrolled in/semester & 4 \\
Core course in program & $78 \%$ \\
\hline
\end{tabular}

\subsection{Student Digital Technology Access and Use in the Classroom}

Questions from the EDUCAUSE Applied Research Study of Undergraduate Students and Information Technology [33] survey were used in order to establish the types of digital technologies that students had access to outside the classroom and what kinds of technologies they were using in their courses. Student digital technology access is illustrated in Table 2.

Table 2. Student technology access and proficiency.

\begin{tabular}{ll}
\hline Technology Access and Proficiency & Percentage \\
\hline Personal rating of computer skills as intermediate/advanced & $63 / 34$ \\
Access to high-speed home Internet connection & 96 \\
Have your own cell phone & 95 \\
Have your own MP3 digital music player & 88 \\
Have your own laptop computer & 82 \\
\hline
\end{tabular}

These results suggest that most survey respondents had access to high-speed Internet connections, cell phones, MP3 players, and laptops outside of the classroom. In the EDUCAUSE Applied Research Study of Undergraduate Students and Information Technology for 2011, eighty percent of the students surveyed also had access to a laptop computer. This EDUCAUSE study [33] and a Pew Internet and American Life report [37] indicate that laptops have overtaken desktops as the computer of choice for adults under the age of 30 .

Fourteen survey items measured frequency of students' use of collaborative learning applications in blended courses under study using a four-point scale (very often, often, sometimes, never). Results are displayed in Table 3.

This table clearly demonstrates that students used digital technologies primarily to access online course materials and communicate with the instructor and other students. More advanced applications such as virtual worlds (e.g., Second Life) and mashups were rarely used by students in the courses that were studied. These findings mirror the results of the EDUCAUSE Applied Research Study of Undergraduate Students and Information Technology for 2011 [33]. 
Table 3. Course digital technology use.

\begin{tabular}{|c|c|c|}
\hline Technology & $\begin{array}{l}\text { Often/ } \\
\text { Very Often }\end{array}$ & $\begin{array}{l}\text { Never/ } \\
\text { Sometimes }\end{array}$ \\
\hline Accessed course materials online (i.e., via Blackboard site, course wiki, etc.) & $96 \%$ & $4 \%$ \\
\hline $\begin{array}{l}\text { Used email or a discussion forum to communicate with the instructor(s) of } \\
\text { this course }\end{array}$ & $49 \%$ & $51 \%$ \\
\hline $\begin{array}{l}\text { Worked in teams or groups using information and communication technology } \\
\text { (i.e., clickers, Blackboard, wikis, blogs, Google Docs, etc.) }\end{array}$ & $48 \%$ & $52 \%$ \\
\hline $\begin{array}{l}\text { Used a MRC Library online database (i.e., EBSCO, ProQuest, etc.) to find } \\
\text { material for a course assignment or project }\end{array}$ & $38 \%$ & $62 \%$ \\
\hline $\begin{array}{l}\text { Used real-time communication tools (i.e., Elluminate, cell phone, chat group, } \\
\text { Internet, instant messaging, etc.) to discuss or complete an assignment with } \\
\text { classmates in this course }\end{array}$ & $38 \%$ & $62 \%$ \\
\hline $\begin{array}{l}\text { Used a social networking application (i.e., Twitter, Facebook, MySpace, Ning, } \\
\text { etc.) for discussion of course material, assignments or project work }\end{array}$ & $34 \%$ & $66 \%$ \\
\hline Used clickers (i.e., personal response systems) in class & $32 \%$ & $68 \%$ \\
\hline Used a computer and/or a digital projector to make a class presentation & $32 \%$ & $68 \%$ \\
\hline $\begin{array}{l}\text { Wiki or other collaborative writing tool (e.g., Google Docs, etc.) for course } \\
\text { assignments or projects }\end{array}$ & $27 \%$ & $73 \%$ \\
\hline $\begin{array}{l}\text { Media sharing application (i.e., YouTube, Flikr, Podomatic, Slideshare) to } \\
\text { create, share or access information for a course assignment or project }\end{array}$ & $18 \%$ & $82 \%$ \\
\hline Blog for course related work such as assignments or projects & $13 \%$ & $87 \%$ \\
\hline $\begin{array}{l}\text { Social bookmarking tool (e.g., Delicious, Furl, Connotea, etc.) to } \\
\text { manage/organize and share online resources in this course }\end{array}$ & $5 \%$ & $95 \%$ \\
\hline $\begin{array}{l}\text { Virtual world application (i.e., Second Life, The Palace, Moove, etc.) for course } \\
\text { assignments or project work }\end{array}$ & $2 \%$ & $98 \%$ \\
\hline $\begin{array}{l}\text { Mashup application (i.e., Visuwords, Quintura, Intel’s Mash Maker, etc.) for } \\
\text { course assignments or project work }\end{array}$ & $1 \%$ & $99 \%$ \\
\hline
\end{tabular}

\subsection{Assessment Practices and Collaborative Learning Applications}

Instructors were asked in pre- and post-course interviews about how they were designing course assessment activities to incorporate student use of collaborative learning applications. All instructors indicated that they were using Blackboard, the institutional learning management system, as a "base camp" with hyperlinks to collaborative learning applications, which provided opportunities for student self-reflection, peer review, and instructor assessment feedback. The institutional learning management system provided students with a common portal (e.g., URL) so that they did not have to remember and find a series of web-based addresses for the interactive learning technologies (Figure 1).

A range of collaborative learning applications were used to support assessment practices in each of the seven blended courses. Digital technologies that were used in specific courses were identified from the interview and focus group transcripts. For example, students used blogs (e.g., Blogger and Word Press) for self-assessment feedback and reflection in the Child Studies and Creativity in the Workplace courses. At the beginning of the semester, students posted an initial journal entry about their personal learning goals for the course and what they thought they already knew about the course content. Then 
at the end of the semester, students created a final journal entry that reflected on what they had learned and how they had changed, grown, and developed throughout the course. In the Child Studies course, the students were also required to post blog entries related to each major course project and assignment (Figure 2). The purpose of these entries was to have students intentionally reflect about what they learned through the process of completing the assessment activity and how they could apply this learning to their future course studies or careers.

Figure 1. Blackboard as the course "Base Camp”.

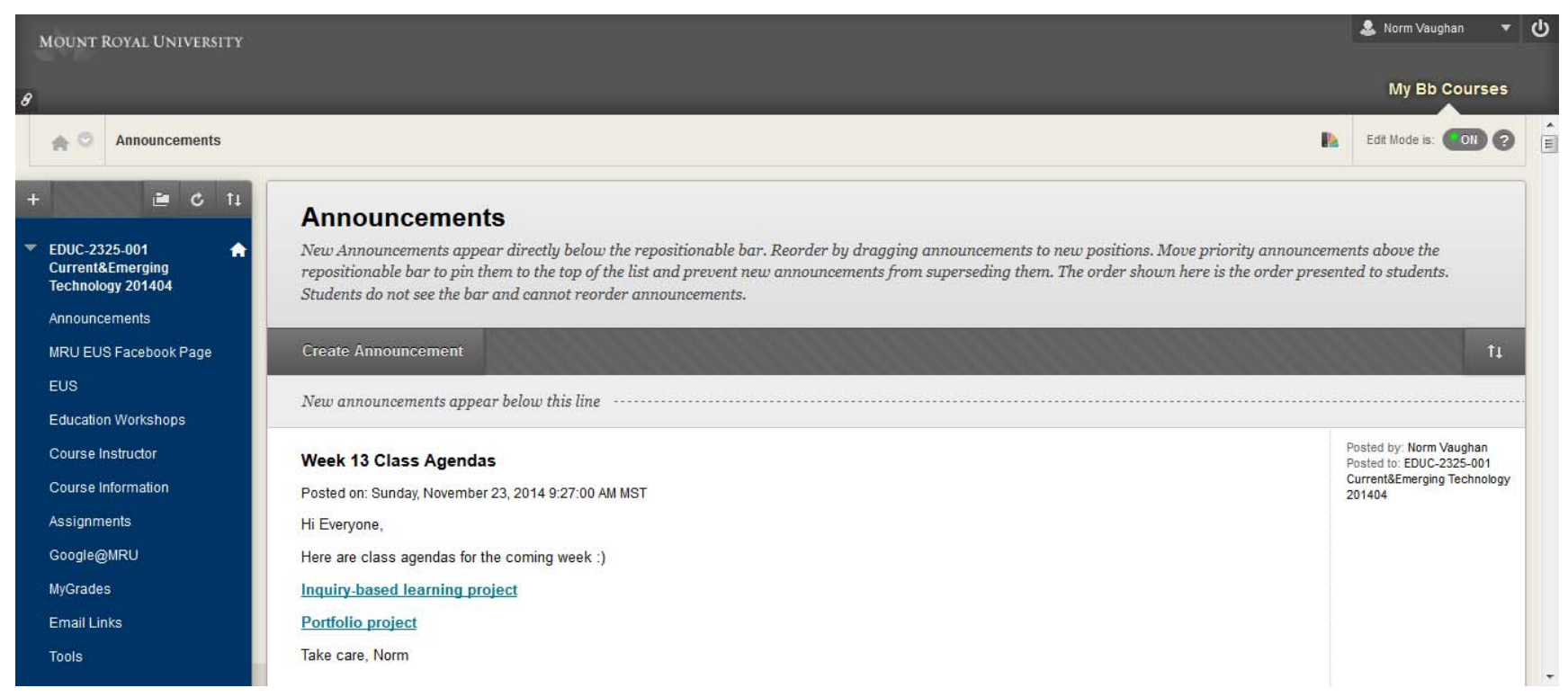

Figure 2. Course assignment reflections.

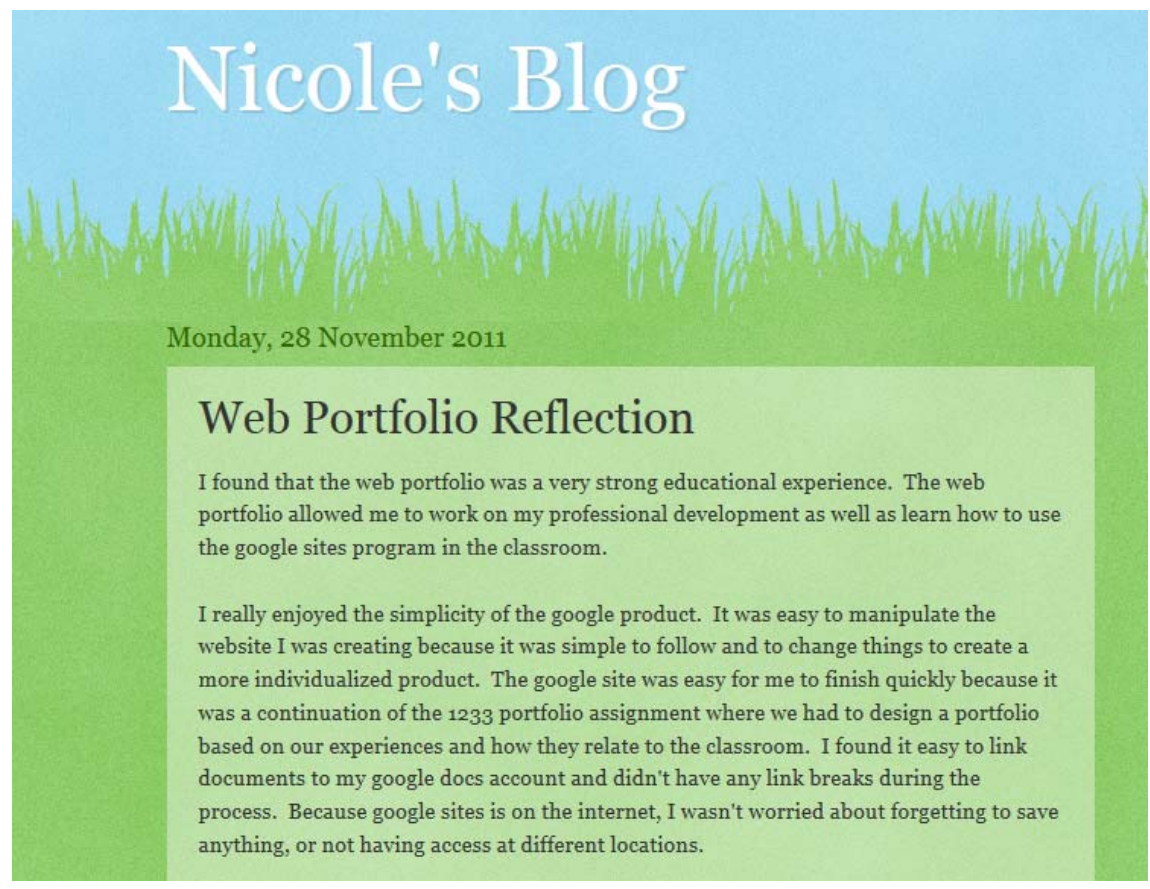

In addition, students in the Creativity in the Workplace course constructed course portfolios using Google Sites in order to showcase their assignments and reflections. 
Personal response systems (e.g., clickers) were used in the Biology and Controversies in Sciences courses for study group quizzes and discussion prompts. Crouch and Mazur [38] describe how clickers can be used to support a form of peer instruction. The process begins with the teacher posing a question or problem. The students initially work individually toward a solution and "vote" on what they believe is the correct answer by selecting the desired numbered or lettered response on their clicker. The results are then projected for the entire class to view. For a good question, there is usually a broad range of responses. Students are then required to compare and discuss their solutions with the person next to them in the classroom in order to come to a consensus. Another "vote" is taken but this time only one response or clicker per group can be utilized. In most circumstances, the range of responses decreases and usually centers around the correct answer. An alternative to this process, in the Controversies to Science course, was to have groups of students generate the quiz questions in advance of the classroom session.

Students in the Biology course also made use of UCLA's Calibrated Peer Review (CPR) tool to provide peer feedback on laboratory reports (Figure 3).

Figure 3. Calibrated peer review tool.

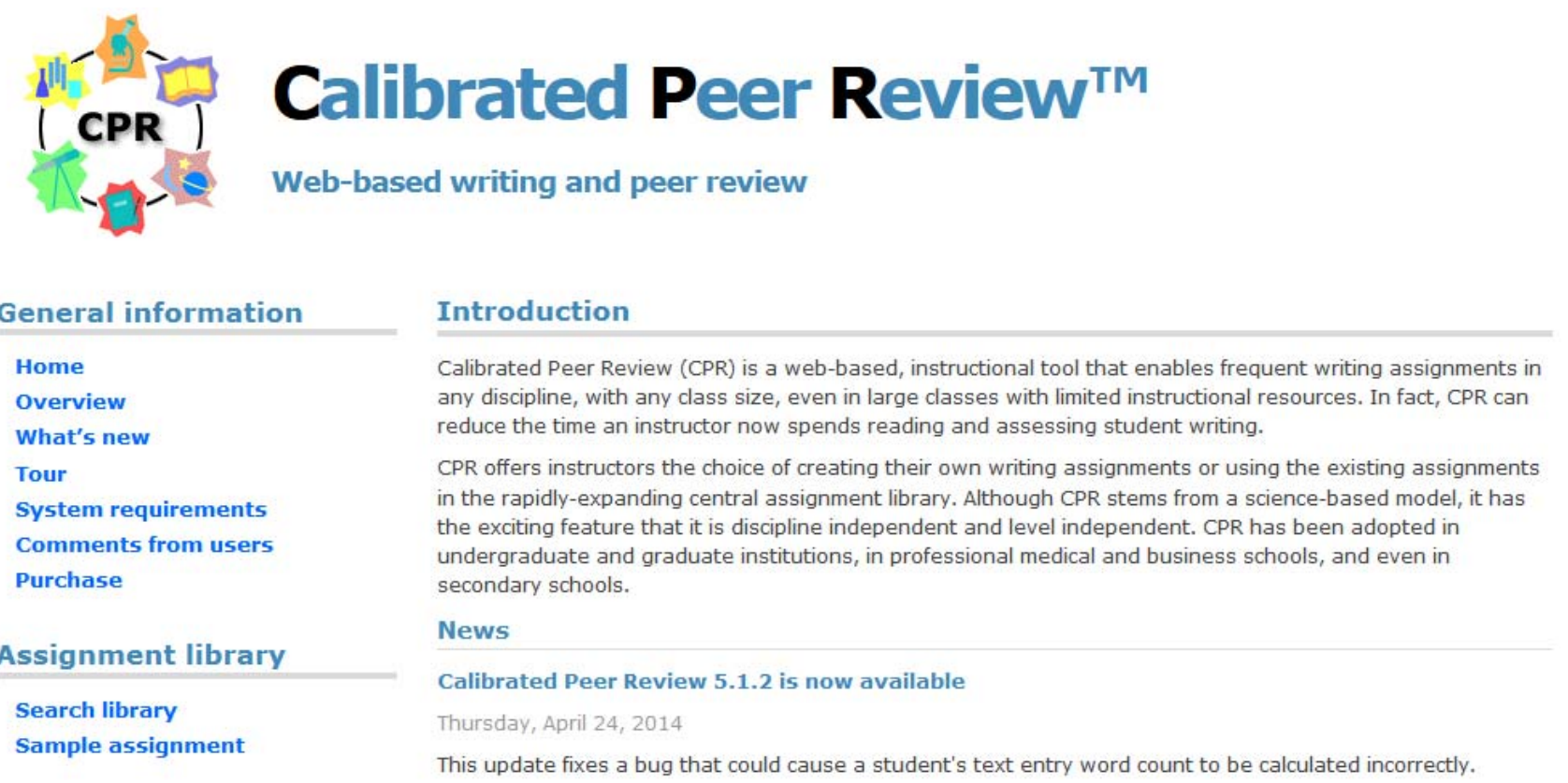

The social networking application Facebook and the group tools in the Blackboard learning management system were used by students in the Communication and Child Studies courses to facilitate communication, collaboration and construction of team-based projects. A wiki (e.g., MediaWiki server) was used by students as a collaborative writing space in the Business course to co-create a set of class notes, which were used to prepare for the midterm and final exams. And, in the Economics course, students used commercial problem solving software (e.g., The Learning Manager (TLM) and Lyryx Learning) for low and medium-stake self-assessment exercises throughout the semester. This type of rapid formative assessment provides students and instructors with weekly feedback on student performance [39]. 


\subsection{Student Perceptions of Assessment Practices and Collaborative Learning Applications}

Survey responses suggest that students perceived high value in the above-noted assessment activities and associated use of collaborative learning technologies. In terms of course satisfaction, $97 \%$ of the students who completed the online survey agreed or strongly agreed that the digital technologies used in the study courses were appropriate for performing the assessment tasks required (Figure 4). Further, 92\% of the students agreed or strongly agreed that they would recommend these courses to other students.

Figure 4. Appropriate technologies for performing the required course assessment tasks.

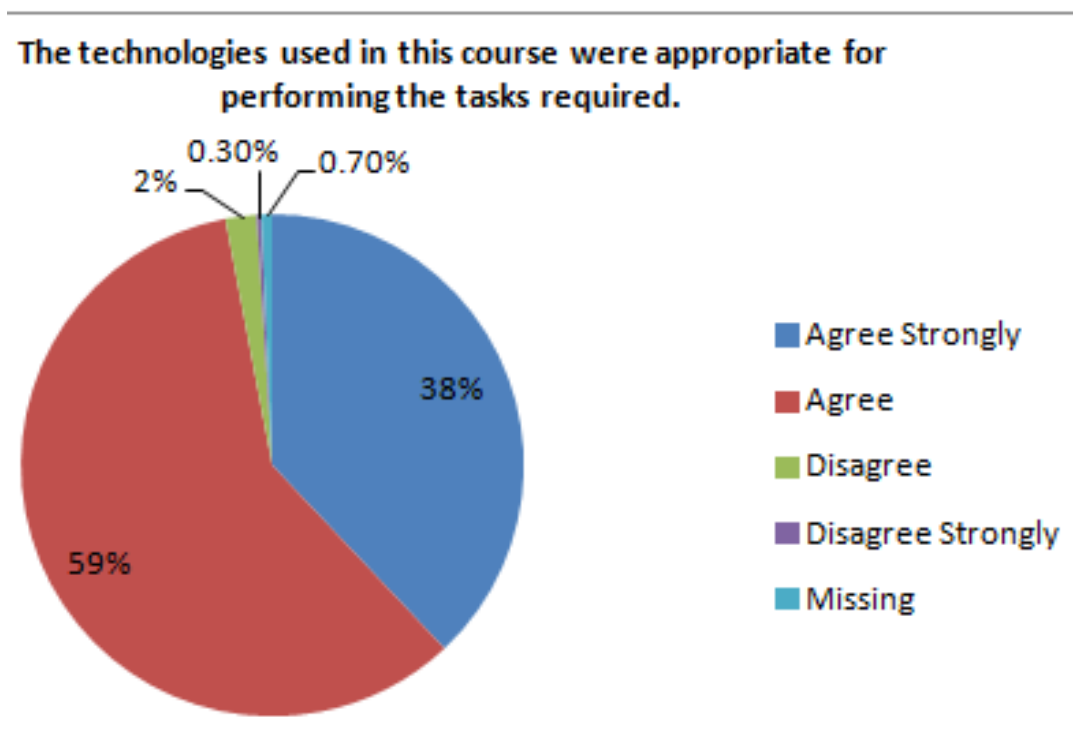

Students commented in each of the focus groups that the most effective aspects of the seven blended courses were the use of the collaborative learning applications, team-based project work, and empathetic instructors. Least effective aspects of these blended courses were the increased workload, lack of clear directions for out-of-class activities, and the emphasis on self-directed learning. In terms of improving the assessment practices in the courses, students recommended that collaborative learning technologies be used to provide more frequent assessment feedback, and that clearer explanation and examples of the required assignments be given. The students also suggested that there should be an increase in the number of low to medium stake assessments, more group work, and a better distribution of assignment deadlines throughout the semester (e.g., avoid having all the major papers, projects, and exams due in the final weeks).

\subsection{Associations between the Use of Collaborative Learning Applications, Engagement and Academic Achievement}

Cronbach alpha coefficients for computed scale scores are summarized in Table 4. All approach or exceed the acceptable level of 0.70 recommended by Nunally [40]. 
Table 4. Alpha coefficients for computed scales.

\begin{tabular}{ll}
\hline Scale & Cronbach Alpha \\
\hline Engagement in effective educational practices (20 items) & 0.83 \\
Active and collaborative learning (7 items) & 0.78 \\
Student-faculty interaction (6 items) & 0.71 \\
Level of academic challenge (6 items) & 0.68 \\
Intensity of course-related technology use (12 items) & 0.69 \\
\hline
\end{tabular}

Correlation coefficients for the association between student final course grades and engagement measures are shown in Table 5. Several small to moderate, statistically significant correlations were observed.

Table 5. Correlations: Final grades and engagement measures.

\begin{tabular}{ll}
\hline Variables & $\mathbf{r}$ \\
\hline Engagement in effective educational practices & $0.303 * *$ \\
Active and Collaborative Learning (ACL) & $0.260 * *$ \\
Level of Academic Challenge (LAC) & $0.181 *$ \\
Student Interactions with Faculty Members (SFI) & $0.148 *$ \\
\hline
\end{tabular}

$$
{ }^{*} p<0.05 ;{ }^{* *} p<0.001 \text {. }
$$

To further probe the association between grades and effective educational practices (EEP), and between grades and active and collaborative learning (ACL), one-way ANOVA was conducted to test for differences in final grade by scale score quartile. As shown in Figures 5 and 6, differences in final grade were statistically significant by ACL and EEP score quartile. In both cases, a 10\% differential in mean final grade is noted between students in quartiles 1 and students in quartile 4. Effect size (Cohen's d) was moderate in magnitude in both cases.

Figure 5. Final course grades by active and collaborative learning (ACL) score quartile.

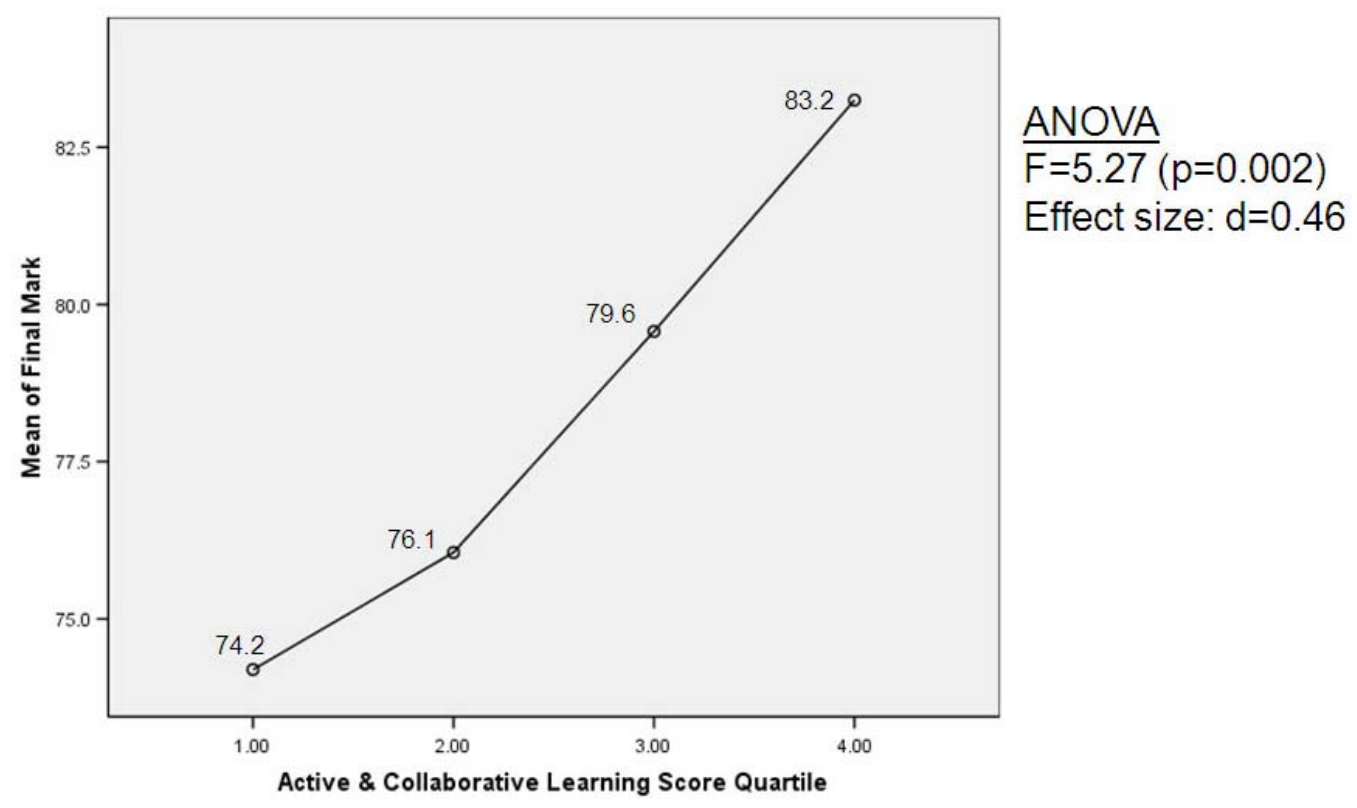


Figure 6. Final course grades by effective educational practices score quartile.

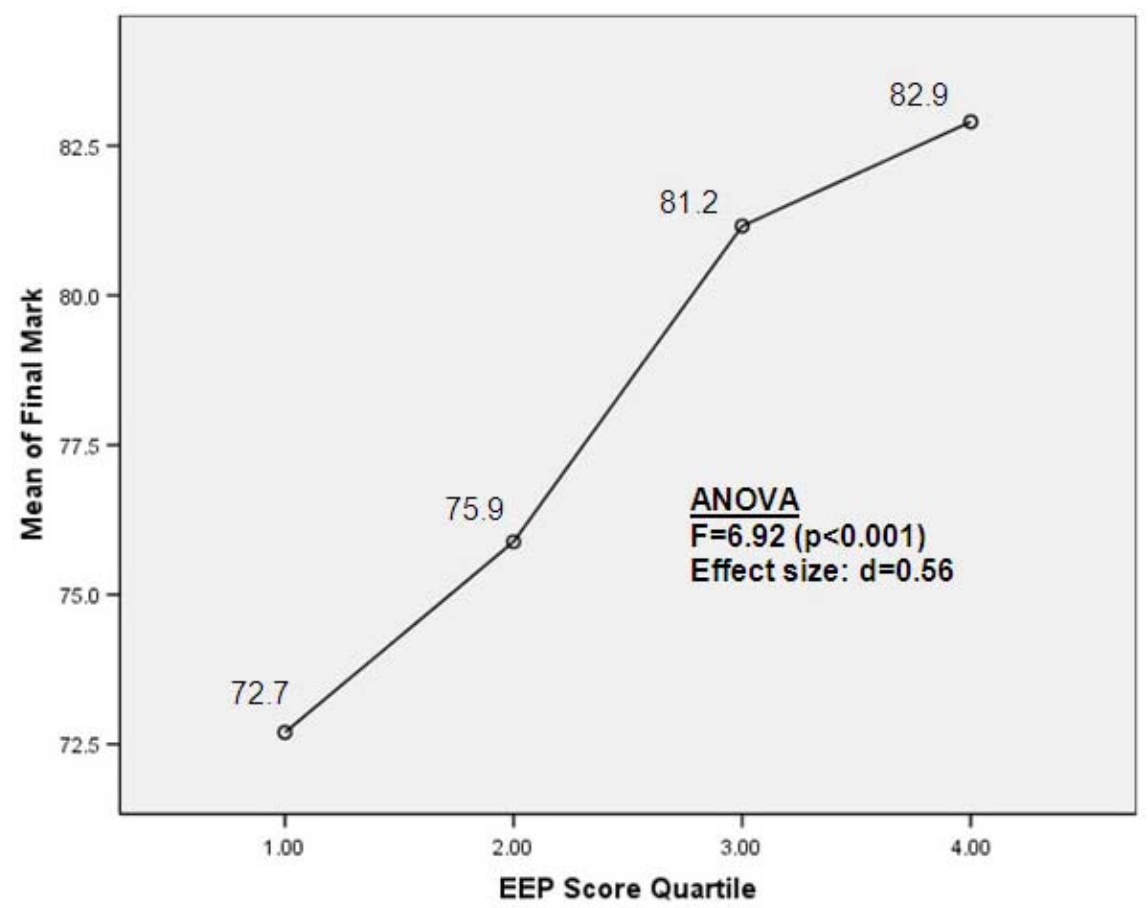

Pearson correlation coefficient for the association between levels of Blackboard use and final grade was $0.270(p<0.001)$. One-way ANOVA was significant for differences in student grade by Blackboard usage quartile ( $F=7.97, p<0.001$, Cohen's $d=0.43$, see Figure 7 ).

Figure 7. Final course grades by blackboard use quartile.

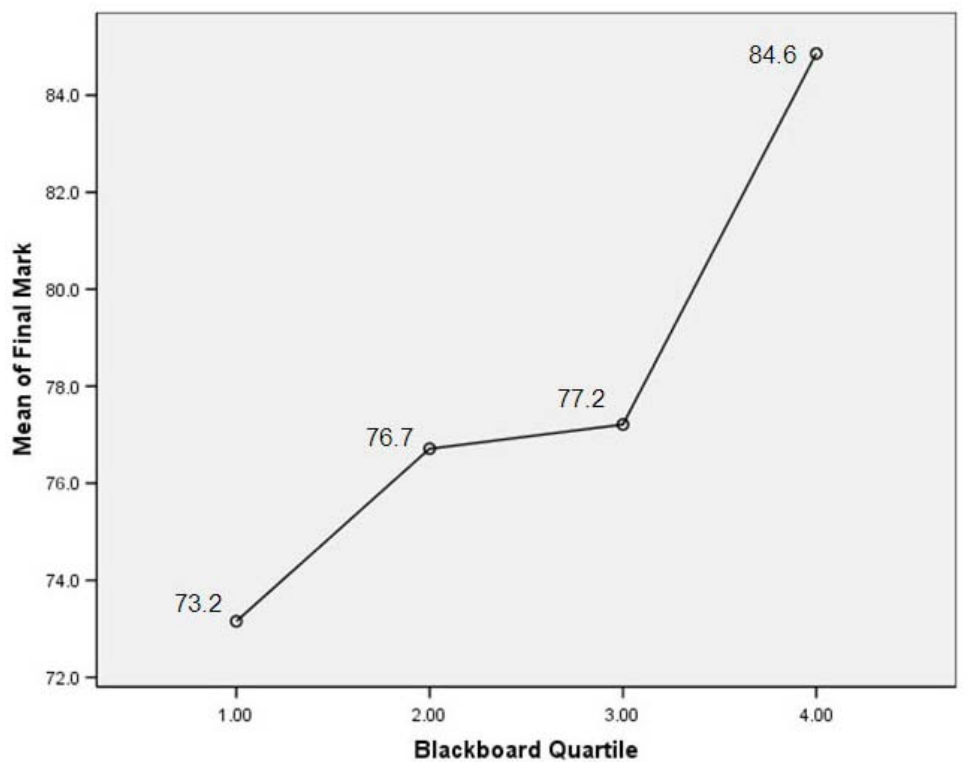

\section{ANOVA}

$F=7.97(p<0.001)$

Effect size: $d=0.43$

The association between intensity of course-related technology use and final grade was non-significant $(r=0.095, p>0.05)$. Correlations between intensity of course-related technology use, Blackboard use, and engagement measures are shown in Table 6. Moderate to strong correlations were observed between intensity of technology use and each of the engagement parameters. 
Table 6. Correlations between engagement, blackboard use and intensity of technology use.

\begin{tabular}{lll}
\hline Engagement Indicators & Blackboard Use & $\begin{array}{l}\text { Intensity of Course-Related } \\
\text { Technology Use }\end{array}$ \\
\hline Engagement in effective educational practices & $\mathrm{r}=0.270 * *$ & $\mathrm{r}=0.643 * *$ \\
Active and collaborative learning & $\mathrm{r}=0.177 * *$ & $\mathrm{r}=0.482 * *$ \\
Student-faculty interaction & $\mathrm{r}=0.189 * *$ & $\mathrm{r}=0.413 * *$ \\
Level of academic challenge & $\mathrm{r}=0.187 * *$ & $\mathrm{r}=0.339 * *$ \\
\hline \multicolumn{2}{c}{$p<0.01}$.
\end{tabular}

\section{Discussion}

The purpose of this study was to investigate the following three questions:

(1) How are instructors designing course assessment activities to incorporate student use of collaborative learning applications in blended courses?

(2) How do students perceive the value of these digital tools?

(3) Is there a correlation between the use of these tools, the level of perceived student engagement in these courses, and academic achievement in blended courses?

\subsection{Assessment Practices and Collaborative Learning Applications}

With regards to the first question, a number of educational researchers [41,42] stated that assessment drives learning in higher education. Entwistle [43] indicates that the design of the assessment activity and the associated feedback can influence the type of learning that takes place in a course or program. For example, standardized tests with minimal feedback can lead to memorization and a surface approach to learning while collaborative group projects can encourage dialogue, richer forms of feedback, and deeper modes of learning.

All seven instructors involved in this study commented, in the post-course interviews, about how they are using collaborative learning applications to design activities that provide students with more frequent opportunities for formative self, peer, and instructor assessment feedback. For example, digital technologies, such as blogs, ePortfolios, and web-based problem solving software, are being used by the students for self-assessment activities. Additionally, tools such as the calibrated peer review tool, wikis, and clickers are enabling students to provide peer-assessment feedback to their classmates. Instructors, and in some blended courses external experts as well, are using all of these collaborative learning applications to observe student performance, diagnose student misconceptions, and provide additional formative assessment feedback. The use of collaborative learning applications to support a triad approach to assessment is illustrated in Figure 8.

An international call for a greater focus on assessment for learning, rather than on assessment for just measurement and accountability of student performance is well documented in the educational research literature [44]. The use of collaborative learning applications to support an increased focus on formative assessment practices may lead to Hattie's [45] vision of a visible teaching and learning framework where "teachers SEE learning through the eyes of their students and students SEE themselves as their own teachers” [45] (p. 238). 
Figure 8. Triad approach to assessment.

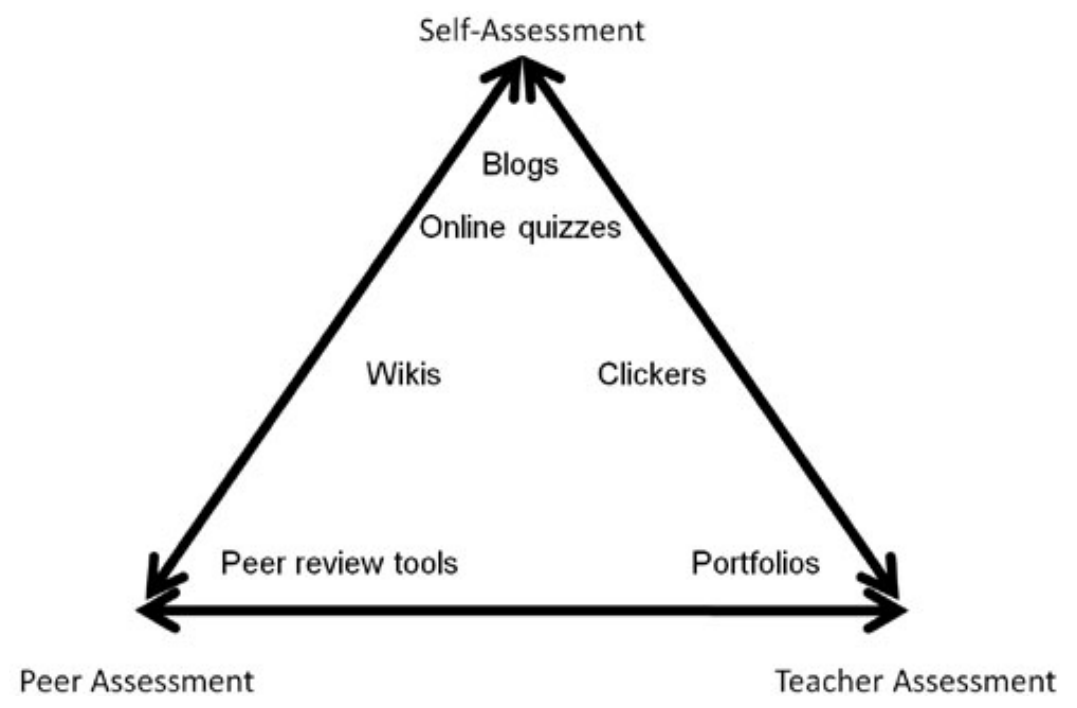

\subsection{Student Perceptions of Assessment Practices and Collaborative Learning Applications}

The findings from the online surveys and focus groups clearly demonstrate that students perceive a high value of using collaborative learning applications to complete assessment activities, if these tools help make the process more effective and efficient. Twigg [46] warns of the dangers of using various forms of technology to create a "course and a half syndrome". This is the common tendency to use collaborative learning applications to cover too much material and include too many assessment activities in a blended course. Both the students and instructors involved in such a blended course quickly become overwhelmed with “content” and forget about the "key concepts and ideas”.

\subsection{Associations between the Use of Collaborative Learning Applications, Engagement and Academic Achievement}

Consistent with prior research [47-49], this study found small to moderate correlations between final course grades and engagement-related measures such as active and collaborative learning, level of academic challenge, student-faculty interaction, and engagement in effective educational practices. This finding suggests that engagement in empirically-supported educational practices is associated with gains in student learning and development. It is a limitation of the present study, however, that controls for other correlates of achievement such as aptitude, prior achievement, and motivation were not in place. It is conceivable that students with the highest aptitude or the greatest motivation were also the students with the highest levels of engagement in these blended courses, raising questions about the observed association between engagement and achievement. Future studies of this type should seek to examine and control for a fuller range of variables thought to influence students' academic achievement [26].

In addition, consistent with prior research [50] was the observed association between intensity of student digital technology use and measures of engagement. Indeed, moderate to strong correlations were noted between digital technology use and engagement-related parameters including active/collaborative learning, student-faculty interaction, level of academic challenge, and engagement in effective 
educational practices. This finding appears to be in keeping with the manner in which collaborative learning applications were deployed in the blended courses under study, and suggests that when thoughtfully used, such digital technologies may have an important role to play in the engagement of today's learner. Whether digital technology use is a form of engagement on its own for current students, or a vehicle for engagement in effective educational practices such as active and collaborative learning is unclear [51], but may be a subject of future study.

\section{Conclusions}

The historical ideal of higher education has been to learn in collaborative communities of inquiry [52]. This study has demonstrated the potential of using collaborative learning applications to design and implement assessment activities to recapture this vision in first year, blended undergraduate courses. The key is to redesign blended courses for active and collaborative learning experiences that enable students to take responsibility for their learning and to validate their understanding through discourse and debate with their peers. The author's hope is that others will be able to use and build upon the results of this study in order to help students at other institutions effectively engage in their academic studies.

\section{Conflicts of Interest}

The author declares no conflict of interest.

\section{References}

1. Regier, P. Using technology to engage the non-traditional student. Educause Rev. 2014, 6, 70-88. Available online: https://net.educause.edu/ir/library/pdf/ERM1454.pdf (accessed on 17 November 2014).

2. Littky, D.; Grabelle, S. The Big Picture: Education is Everyone's Business; Association for Supervision and Curriculum Development: Alexandria, VA, USA, 2014.

3. Csikszentmihalyi, M. Flow: The Psychology of Optimal Experience; Harper and Row: New York, NY, USA, 1990.

4. Pink, D.H. Drive: The Surprising Truth about What Motivates Us; Riverhead Books: New York, NY, USA, 2009.

5. Fullan, M. Stratosphere: Integrating technology, pedagogy, and change knowledge; Pearson Canada: Toronto, Canada, 2012.

6. National Survey of Student Engagement. Experiences that Matter: Enhancing Student Learning and Success-Annual Report 2007; Center for Postsecondary Research: Bloomington, IN, USA, 2007.

7. Dziuban, C.; Graham, C.; Picciano, A.G. Research Perspectives in Blended Learning, 2nd ed.; Routledge, Taylor and Francis: New York, NY, USA, 2013.

8. Williams, J. Blending into the Background. E-Learning Age Magazine, 28 September 2013, p. 1 
9. Allen, I.E.; Seaman, J. Class Differences: Online Education in the United States, 2010; Babson Survey Research Group, The Sloan Consortium, 2010. Available online: http://sloanconsortium.org/ publications/survey/class_differences (accessed on 17 November 2014).

10. Clark, D. Blend it Like Beckham; Epic Group PLC: East Sussex, UK, 2003.

11. Sharpe, R.; Benfield, G.; Roberts, G.; Francis, R. The Undergraduate Experience of Blended e-Learning: A Review of UK Literature and Practice; Higher Education Academy: London, UK, 2006.

12. Williams, C. Learning on-line: A review of recent literature in a rapidly expanding field. J. Furth. High. Educ. 2002, 26, 263-272.

13. Bleed, R. A hybrid campus for a new millennium. Educause Rev. 2001, 36, 16-24.

14. Garnham, C.; Kaleta, R. Introduction to Hybrid Courses. Teach. Technol. Today 2002, 8, 1-4. Available online: http://hccelearning.files.wordpress.com/2010/09/introduction-to-hybridcourse1.pdf (accessed on 23 November 2014).

15. Littlejohn, A.; Pegler, C. Preparing for Blended e-Learning: Understanding Blended and Online Learning (Connecting with E-Learning); Routledge: London, UK, 2007.

16. Norberg, A.; Dziuban, C.D.; Moskal, P.D. A time-based blended learning model. Horizon 2011, 19, 207-216.

17. Garrison, D.R.; Vaughan, N.D. Blended Learning in Higher Education; Jossey-Bass: San Francisco, CA, USA, 2008.

18. Arabasz, P.; Boggs, R.; Baker, M.B. Highlights of e-Learning Support Practices. Educause Center for Applied Research: Research Bulletin, 29 April 2003, p. 9.

19. Graham, C.R. Blended learning systems: Definitions, current trends, and future directions. In The Handbook of Blended Learning: Global Perspectives, Local Designs; Bonk, C., Graham, C., Eds.; Pfeiffer: San Francisco, CA, USA, 2006; pp. 3-21.

20. Mayadas, F.A.; Picciano, A.G. Blended learning and localness: The means and the end. J. Asynchronous Learn. Netw. 2007, 11, 3-7.

21. Moskal, P.D.; Dziuban, C.D.; Hartman, J. Blended learning: A dangerous idea? Intern. High. Educ. 2013, 18, 15-23.

22. Leslie, S.; Langdon, B. Social Software for Learning: What is it, Why Use it? The Observatory on Borderless Higher Education: London, UK, 2008.

23. Garrison, D.R.; Archer, W. A Transactional Perspective on Teaching and Learning: A Framework for Adult and Higher Education; Pergamon: Oxford, UK, 2000.

24. Dewey, J. Democracy and education: An introduction to the philosophy of education; Macmillan: New York, NY, USA, 1916.

25. National Survey of Student Engagement. Bringing the Institution into Focus-Annual Report 2014; Center for Postsecondary Research: Bloomington, IN, USA, 2014.

26. Pace, C. Measuring the quality of student effort. Curr. Issues High. Educ. 1980, 2, 10-16.

27. Astin, A. Student involvement: A developmental theory for higher education. J. Coll. Stud. Dev. 1999, 49, 518-529.

28. Chickering. A.W.; Gamson, Z.F. Development and adaptations of the seven principles for good practice in undergraduate education. New Dir. Teach. Learn. 1999, 80, 75-82. 
29. Pascarella, E.; Terenzini, P. How College Affects Students: A Third Decade of Research, 2nd ed.; Jossey-Bass: San Francisco, CA, USA, 2005.

30. Stringer, E.T. Action Research, 3rd ed.; Sage Publications: London, UK, 2007.

31. Creswell, J.W. Research Design, 4th ed.; Sage: Thousand Oaks, CA, USA, 2013.

32. Ouimet, J.A.; Smallwood, R.A. CLASSE-The class-level survey of student engagement. Assess. Update 2005, 17, 24-35.

33. Dahlstrom, E.; de Boor, T.; Grunwald, P.; Vockley, M. The ECAR Study of Undergraduate Students and Information Technology, 2011; Research Report; Educause: Boulder, CO, USA, 2011. Available online: http://net.educause.edu/ir/library/pdf/ERS1103/ERS1103W.pdf (accessed on 17 November 2014).

34. Ehrmann, S.C.; Zuniga, R.E. The Flashlight Evaluation Handbook; Corporation for Public Broadcasting: Washington, DC, USA, 1997.

35. Patton, M.Q. Qualitative Evaluation and Research Methods, 2nd ed.; Sage Publications: Newbury Park, CA, USA, 1990.

36. Canadian University Survey Consortium (CUSC). Undergraduate Student Survey; CUSC: Ottawa, ON, Canada, 2013.

37. Lenhart, A.; Purcell, K.; Smith, A.; Zickuhr, K. Social media \& mobile internet use among teens and young adults. Pew Intern. Am. Life Proj. 2010. Available online: http://www.pewinternet.org/2010/02/03/social-media-and-young-adults/ (accessed on 17 November 2014).

38. Crouch, C.H.; Mazur, E. Peer instruction: Ten years of experience and results. Am. J. Phys. 2001, 69, 970-977.

39. Birenbaum, M.; Breuer, K.; Cascallar, E.; Dochy, F.; Dori, Y.; Ridgway, J. A learning integrated assessment system. Educ. Res. Rev. 2006, 1, 61-67.

40. Nunnally, J.C. Psychometric Theory, 2nd ed.; McGraw-Hill: New York, NY, USA, 1978.

41. Thistlethwaite, J. More thoughts on assessment drives learning. Med. Educ. 2006, 40, 1149-1150.

42. Hedberg, J.; Corrent-Agostinho, S. Creating a postgraduate virtual community: Assessment drives learning. Educ. Media Int. 2000, 37, 83-90.

43. Entwistle, N.J. Approaches to studying and levels of understanding: The influences of teaching and assessment. In Higher Education: Handbook of Theory and Research; Smart, J.C., Ed.; Agathon Press: New York, NY, USA, 2000; Volume XV, pp. 156-218.

44. Yeh, S.S. The cost-effectiveness of raising teacher quality. Educ. Res. Rev. 2009, 4, $220-232$.

45. Hattie, J. Visible Learning: A Synthesis of over 800 Meta-Analyses Relating to Achievement; Routledge: New York, NY, USA, 2009.

46. Twigg, C.A. Improving learning and reducing costs: New models for online learning. Educause Rev. 2003, 38, 29-38.

47. Carini, R.; Kuh, G.; Klein, S. Student engagement and student learning: Testing the linkages. Res. High. Educ. 2006, 47, 1-32.

48. Kuh, G.D.; Kinzie, J.; Cruce, T. Connecting the Dots: Multi-Faceted Analyses of the Relationships between Student Engagement Results from the NSSE and the Institutional Practices and Conditions that Foster Student Success, 2007. Available online: http://nsse.iub.edu/pdf/Connecting_the_Dots_ Report.pdf (accessed on 16 November 2014). 
49. Kuh, G.D. High Impact Educational Practices: What They Are, Who Has Access to Them, and Why They Matter; Association of American Colleges and Universities: Washington, DC, USA, 2008.

50. National Survey of Student Engagement. Assessment for Improvement: Tracking Student Engagement over Time-Annual Results 2009; Indiana University Center for Postsecondary Research: Bloomington, IN, USA, 2009.

51. Coates, H. A model of online and general campus-based student engagement. Assess. Eval. High. Educ. 2007, 32, 121-141.

52. Lipman, M. Thinking in Education; Cambridge University Press: Cambridge, UK, 1991.

(C) 2014 by the authors; licensee MDPI, Basel, Switzerland. This article is an open access article distributed under the terms and conditions of the Creative Commons Attribution license (http://creativecommons.org/licenses/by/4.0/). 